\title{
Undersøkelse og behandling av brudd og pseudartrose i skafoid
}

\begin{abstract}
BAKGRUNN Brudd i båtbeinet, os scaphoideum, rammer ca. 2000 pasienter årlig i Norge. Utredning og diagnostikk kan være vanskelig, og frakturer blir oversett. Tradisjonelt har skafoidfrakturer blitt gipset, men siste tiår har skruefiksering av frakturer økt og gitt håp om høyere tilhelingsfrekvens og bedre funksjon. Noen skafoidfrakturer blir ikke diagnostisert i akuttfasen og noen gror ikke etter behandling. Pasientene kan da ende opp med en smertefull psuedartrose. Formålet med denne artikkelen er å gi en oversikt over utredning, behandling og resultater etter skafoidfraktur.
\end{abstract}

KUNNSKAPSGRUNNLAG Artikkelen er basert på søk på PubMed og forfatternes egne kliniske erfaringer.

RESULTATER Primær diagnostisering av skafoidfraktur og etterfølgende behandling i gips gir meget godt klinisk resultat. Kirurgisk behandling bør begrenses til dislokerte frakturer, frakturer som del av større håndrotsskader og unntaksvis hos andre. Resultater på høyde med gipsbehandling oppnås av erfarne kirurger på dette feltet. Ubehandlet skafoidfraktur fører ofte til smertefull pseudartrose med påfølgende feilstilling i håndrotsknoklene og sekundær artrose. Denne utviklingen kan motvirkes ved at eldre frakturer opereres med beintransplantasjon, intern fiksasjon og gipsimmobilisering.

FORTOLKNING Norske rutiner ved behandling av skafoidfraktur/pseudartrose er i samsvar med internasjonalt dokumentert god behandling. Utredning av håndrotssmerter etter fall kan bedres ved å klinisk teste for skafoidfraktur og ved radiologisk utredning med fire håndrotsprojeksjoner. Ved klinisk mistanke, men manglende røntgenfunn bør det henvises til CT- eller MR-undersøkelse.

Os scaphoideum er en av åtte knokler i håndroten. Om lag halvparten av beinet er dekket av leddbrusk. Det artikulerer med radius, lunatum, capitatum, trapezoid og trapezium. Tidligere kadaverstudier viste retrograd hovedsirkulasjon i skafoid med inngang $\mathrm{i}$ beinet rundt distale pol. Dette ble antatt å gi en sårbar sirkulasjon av den proksimale delen av knokkelen (1), lik caput femoris hos voksne. I nyere kadaverstudier har man imidlertid påvist mindre sårbar sirkulasjon med anastomoser til alle deler av skafoid (2). Dette forklarer den gode tilhelingsevnen ved tidlig diagnostikk og behandling. Med unntak av frakturer helt distalt gjennom skafoids tuberkel (som nesten uten unntak gror med gips i seks uker) er alle brudd intraartikulære. Kombinasjonen av liten kontaktflate mellom bruddfragmentene og store bevegelser rundt skafoid ved bøy og strekk $i$ håndleddet gir høy risiko for manglende tilheling om bruddet ikke stabiliseres med gips eller intern fiksasjon (3).

Skafoidfraktur rammer menn ca. fire ganger hyppigere enn kvinner, med en topp $i$ alderen 20-40 år. Anslått årlig norsk insidens er 1 800-2 $200(4,5)$, hvorav ca. 5\% er nyoppdagede pseudartroser (6). Nesten alle norske sykehus og skadestuer behandlet i 2006 akutte frakturer med gipsimmobilisering i 8-12 uker. De fleste skafoidpseudartroser ble henvist til håndkirurger og ope- rert med beintransplantasjon og intern fiksasjon fulgt av gipsimmobilisering (7). Formålet med denne gjennomgangen er å gi en oversikt over utredning, behandling og resultater etter skafoidfraktur.

\section{Kunnskapsgrunnlag}

Vi har gjennomført følgende litteratursøk på PubMed med gitte eksklusjonskriterier:

- «scaphoid» og «fracture» (filter: randomized controlled trial): 36 treff, 14 etter eksklusjon.

- «scaphoid» og «fracture» og «treatment» (filter: english, human og abstrakt tilgjengelig, siste 40 år, søkeord i tittel eller abstrakt): 281 treff, 111 etter eksklusjon. 50 av de 111 var oversiktsartikler.

- «scaphoid» og «nonunion» eller «nonunion» (filter: english, human og siste 40 år, søkeord i tittel eller abstrakt): 159 treff, 59 etter eksklusjon. 12 av de 59 var oversiktsartikler, to var randomiserte studier.

Vi ekskluderte artikler der skafoid ikke var tema og kadaverstudier av anatomi, biomekanikk eller operasjonsteknikker. Publikasjoner der skafoidfraktur var omtalt som en del av større håndskader (radiusfraktur/håndrotsfraktur/ligamentskade) ble ekskludert. Epidemiologiske studier, artikler om følgetilstander, enkeltkasuistikker, ekspertmeninger eller rapporter ble også ekskludert. Etter å ha

\section{Ole Reigstad}

ole.reigstad@gmail.com

Rasmus Thorkildsen

Christian Grimsgaard

Seksjon for overekstremitets- og mikrokirurgi Ortopedisk avdeling

Oslo universitetssykehus, Rikshospitalet

Knut Melhuus

Oslo skadelegevakt

Oslo universitetssykehus

\section{Magne Røkkum}

Seksjon for overekstremitets- og mikrokirurgi Ortopedisk avdeling

Oslo universitetssykehus, Rikshospitalet

बb

Engelsk oversettelse på www.tidsskriftet.no

\section{HOVEDBUDSKAP}

Skafoidfraktur bør mistenkes ved smerter i håndroten etter fall

Røntgen av håndroten avslører de fleste skafoidfrakturer, men ved tvil bør det utredes med CT, MR eller gjentatt røntgen

Nesten alle skafoidfrakturer tilheler etter gipsbehandling i 12 uker, og pasienten gjenvinner full håndleddsfunksjon

Manglende kontakt med lege og ufullstendig utredning er de vanligste årsakene til ubehandlede brudd og utvikling av skafoidpseudartrose 


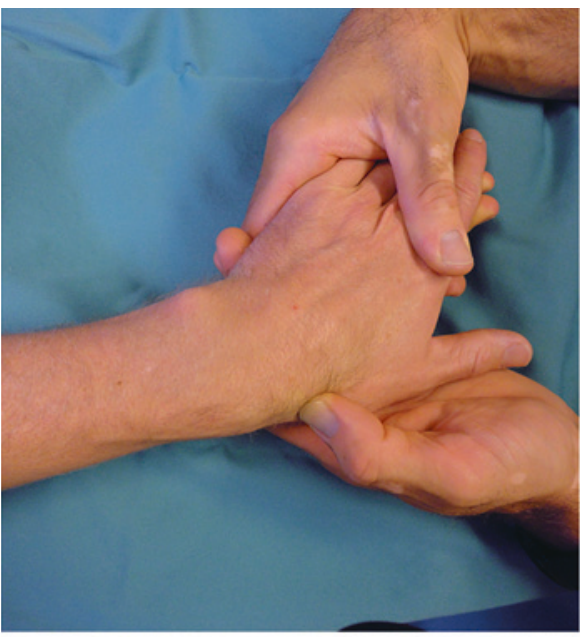

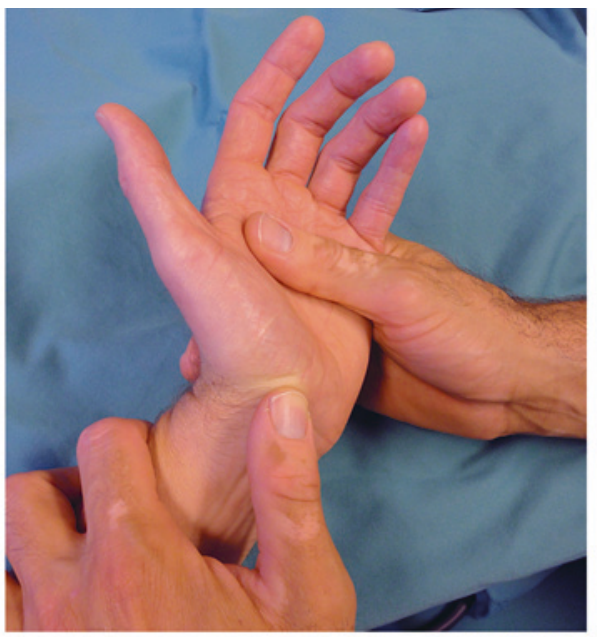

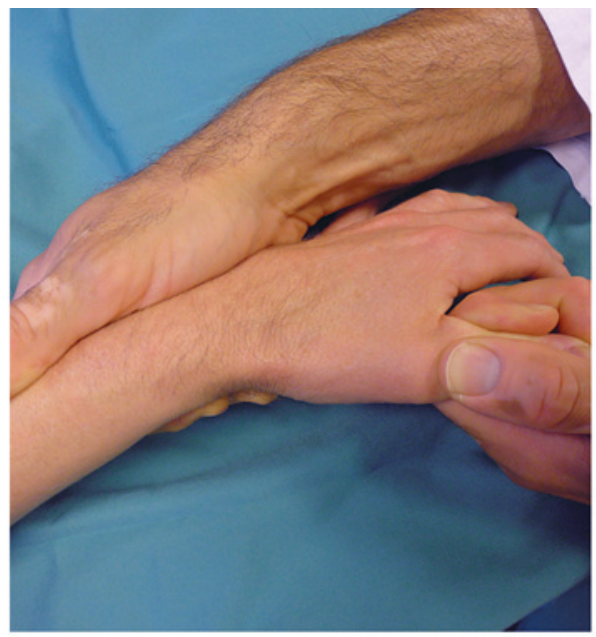

c

Figur 1 Klinisk undersøkelse av mistenkt skafoidfraktur. a) Palpasjon av skafoid i «snusdåsen» med ulnardeviert håndledd, b) kompresjon av skafoid tuberkel, cl stuking av skafoid i tommelens lengderetning

ekskludert duplikater satt vi igjen med 160 artikler. Vi leste igjennom sammendragene fra alle disse artiklene. Forfatterne har omfattende erfaring med behandling av håndrotsskader og brudd i os scaphoideum. Denne oversikten er basert på de prospektive studiene samt det vi oppfatter som de mest relevante og representative oversiktsartiklene/ metaanalysene og retrospektive studiene, til sammen 37 artikler, i tillegg til egen erfaring med problemstillingen.

\section{Resultater}

\section{Studienes kvalitet}

Til tross for mange publikasjoner som omhandler skafoidproblemstillinger, er det få randomiserte studier, og ingen er gjennomført med blinding av pasient eller oppfølgende helsepersonell. De fleste studiene er retrospektive eller kasusserier av lav kvalitet. Metodeproblemene omfatter varierende grad av preoperativ vurdering, manglende sammenlikning og ingen randomisering av behandlingene, forskjellig radiologisk utredning og oppfølging, varierende oppfølgingstid og ulike preoperative- og oppfølgingsparametere. Det er vanskelig å lage gode oversiktsartikler og metaanalyser, og det foreligger ingen Cochrane-anbefalinger.

\section{Utredning av skafoidfraktur}

Pasienter med smerter i håndroten etter fall bør undersøkes klinisk med tanke på skafoidfraktur. Den kliniske undersøkelsen skal omfatte palpasjon i «den anatomiske snusdåsen» med håndleddet ulnardeviert, der hele midtre del av skafoid kan palperes mellom extensor pollicis longus og abductor pollicis longus/extensor pollicis brevis. Dessuten palperes den volare skafoidtuberkelen, og tommelen stukes i skafoids lengderetning (fig 1).
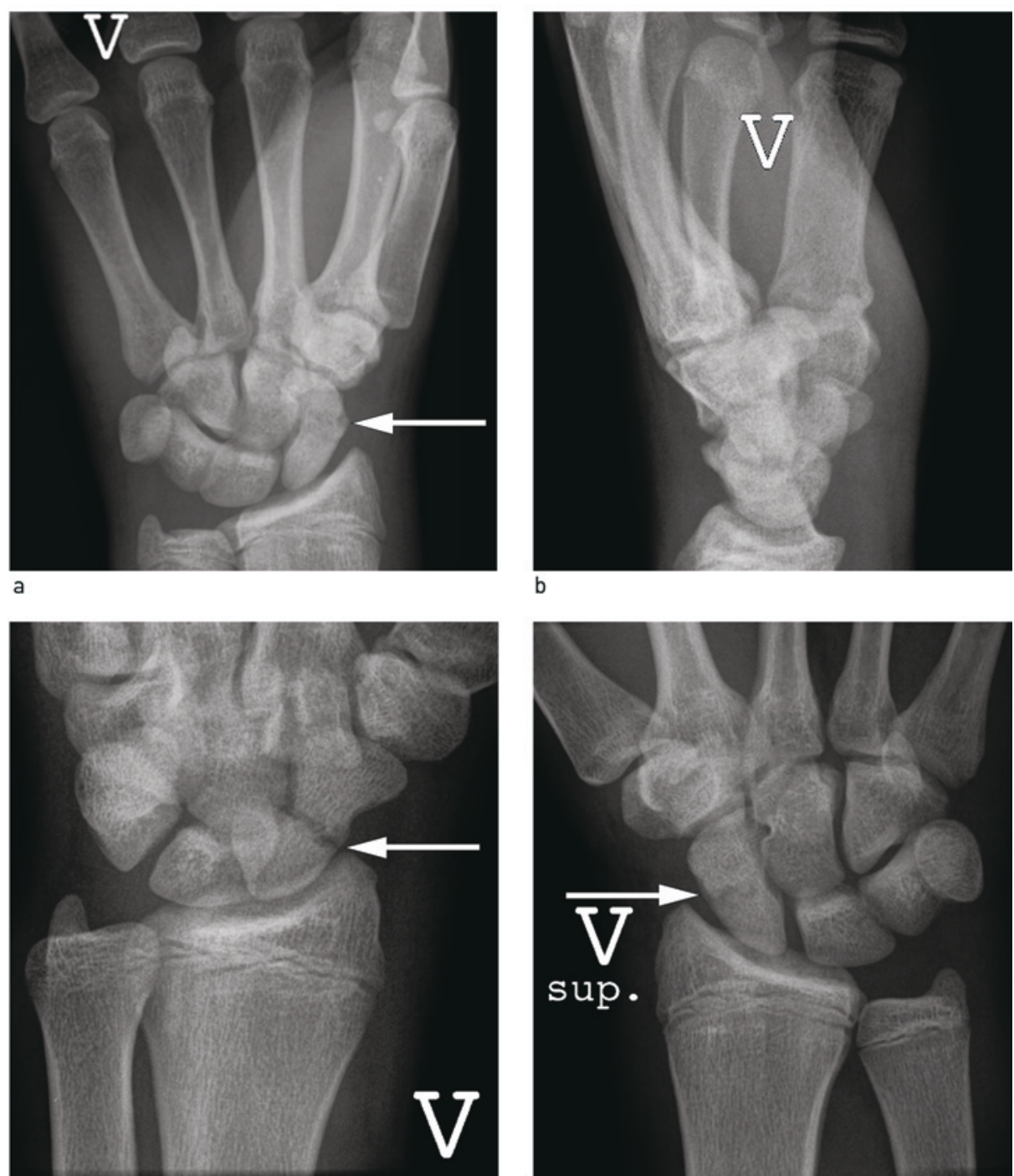

c

b

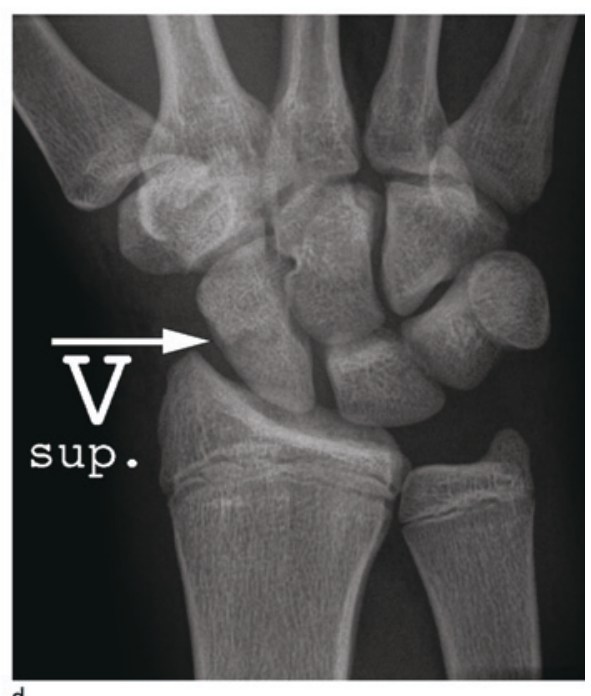

d

Figur 2 Standard røntgenprojeksjoner ved mistanke om skafoidfraktur, pil der frakturen er synlig. a) Frontprojeksjon, b) sideprojeksjon (vanskelig å identifisere fraktur), c) skrå/oblique projeksjon, d) supinert projeksjon 

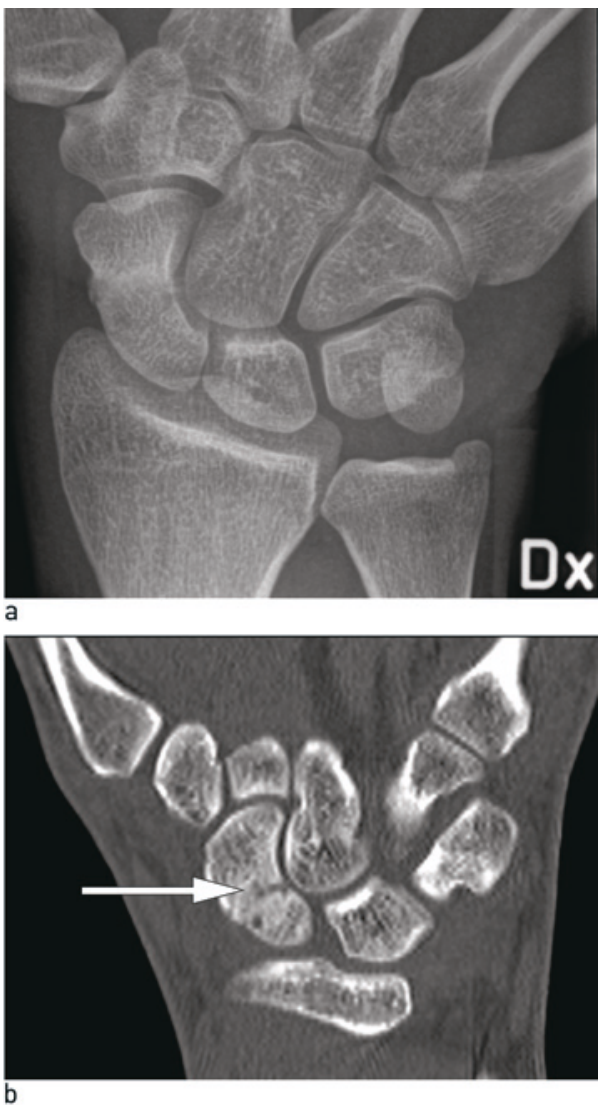

Figur 3 Akutt skafoidfraktur, ikke synlig på standard røntgenbilder. al Frontal projeksjon, oversiktsbilde (vanskelig å se frakturlinjer i skafoid), b) CT viser frakturlinje, markert med pil

Testene har høy sensitivitet (100 \% når alle tre testene er positive (8)) og dermed høy negativ prediktiv verdi. Den positive prediktive verdien er lavere $(58 \%)$. Positiv test må derfor føre til videre utredning $(8,9)$.

De fire radiologiske standardprojeksjonene (fig 2) avslører de fleste frakturer, men noen brudd er ikke synlige på initiale bilder. Pasienter med positive kliniske funn og negative funn på røntgenbilder må derfor følges videre. De kan enten avklares umiddelbart med MR/CT eller gipses og kontrolleres klinisk og røntgenologisk etter to uker. Ved fortsatt klinisk mistanke og negativt røntgenbilde tas CT eller MR slik at fraktur kan bekreftes eller avkreftes (fig 3). MR og $\mathrm{CT}$ har begge $100 \%$ sensitivitet. CT vil bedre avsløre dislokasjon og tegn på eldre fraktur eller pseudartrose (10). Om man har mulighet, bør man avklare problemstillingen umiddelbart med supplerende bildediagnostikk, slik at pasienten slipper unødvendig gipsimmobilisering. Se flytskjema for utredning av mistenkt skafoidfraktur (fig 4).

\section{Behandling av fersk skafoidfraktur}

De fleste retrospektive oppfølgingsstudiene viser høy tilhelingsfrekvens $(89-100 \%)$ og

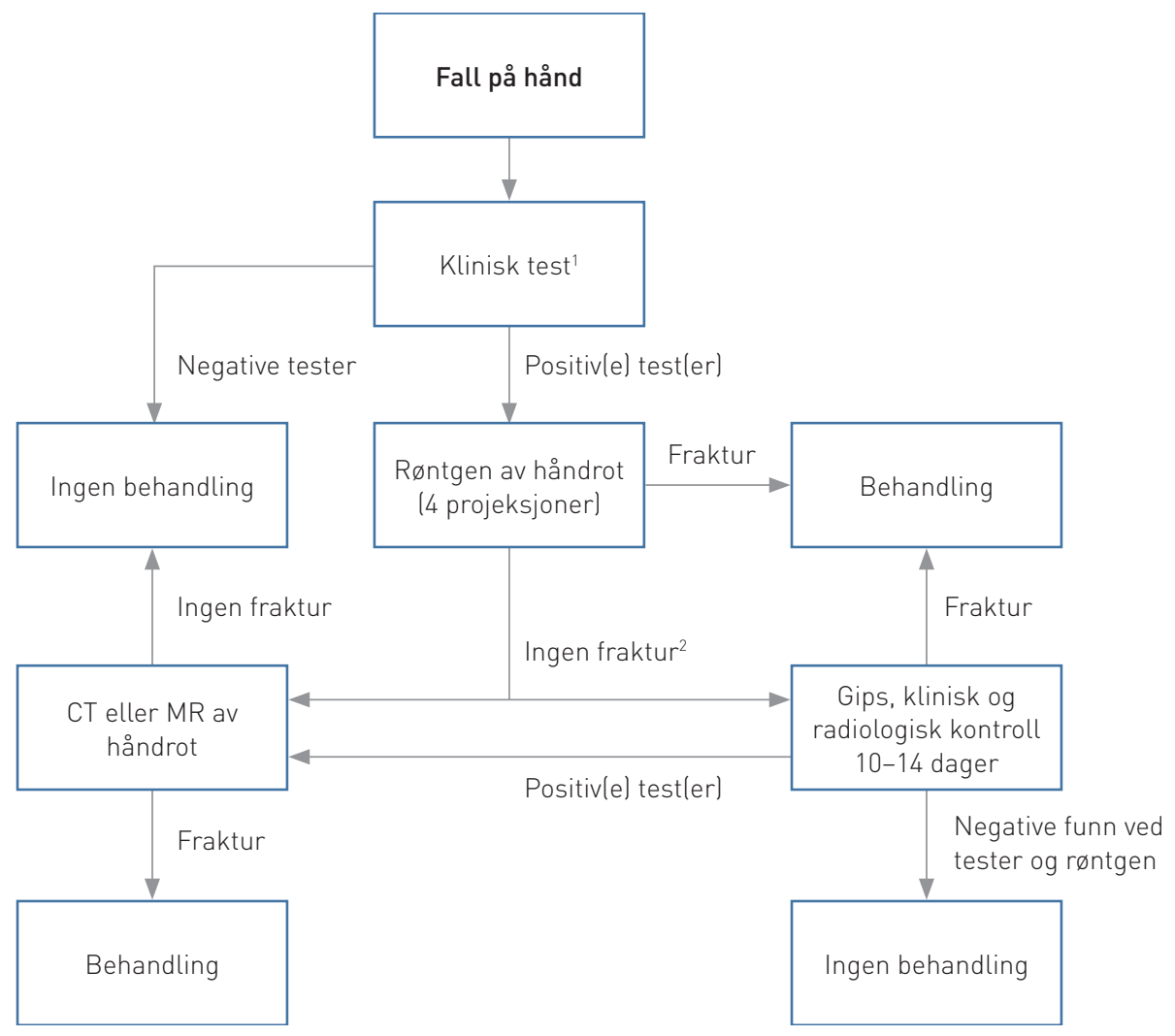

Figur 4 Forslag til utredning av mistenkt skafoidfraktur

${ }^{1}$ Klinisk test består av palpasjon av den anatomiske snusdåsen, palpasjon av skafoidtuberkel og tommelstukning $\mathrm{i}$ lengderetning

${ }^{2}$ Umiddelbar CT/MR er å foretrekke fremfor gipsing hvis praktisk mulig

god håndleddsfunksjon både etter gipsimmobilisering og etter operasjon $(4,11,12)$. Gipsbehandling må starte tidlig. En forsinkelse på fire uker gir dramatisk økning $i$ frekvensen av pseudartrose og forsinket tilheling (> 80\%) (13).

Forskjellige typer gips (med eller uten tommel immobilisert, lett flektert eller ekstendert håndledd, under eller over albuen) er sammenliknet $i$ tre randomiserte kontrollerte studier (14-16) uten forskjell i tilhelingsfrekvens (89-96\%) eller håndleddsfunksjon. I seks randomiserte kontrollerte studier uten blinding ble 8-12 ukers gipsimmobilisering sammenliknet med skruefiksering (17-22). Bruddet ble vurdert som tilhelet om beintrabekler krysset frakturspalten på de fire nevnte projeksjonene. Ved tvil ble tilhelingen avklart med CT. Operasjon ga noe bedre håndleddsfunksjon etter tre måneder, men ikke etter 6-12 måneder. Begge grupper oppnådde utmerket håndleddsfunksjon, men de opererte fikk imidlertid mer artrose i trapezium-skafoidleddet der skruen ble introdusert. Med unntak av i én studie, som også inkluderte dislokerte og komminute brudd (23), ble det ikke funnet signifikante forskjeller i tilhelingsfre- kvens (87-100\%). Det er laget flere metaanalyser og oversiktsartikler av litteraturen, inkludert de få prospektive studiene som finnes. I tre metastudier ble det ikke funnet forskjell i tilhelingsfrekvens. I én studie fant man en liten økt relativ risiko for pseudartrose ved gipsimmobilisering, men ikke når det var tatt hensyn til frafall av pasienter ved oppfølging. Komplikasjonsfrekvensen er signifikant høyere ved kirurgi, men de fleste komplikasjoner er milde og forbigående (24-27). Det er konsensus om at dislokerte frakturer og frakturer som ledd i håndrotsfrakturdislokasjoner bør opereres med intern fiksasjon $(28,29)$. Hvis man ser dislokasjon på røntgen, bør frakturen utredes med CT og vurderes for operasjon. Gips i slike tilfeller gir ikke nok stabilitet for tilheling. Det sikreste er å gipsbehandle alle i 12 uker før man kontrollerer med røntgen.

\section{Behandling av skafoidpseudartrose}

En skafoidfraktur som ikke viser tegn til tilheling etter 3-4 måneder med gips, vil ikke gro med ytterligere konservativ behandling og bør henvises til kirurgi (13). En gjennomgang av 270 skafoidpseudartroser viste at nesten halvparten av pasientene ikke opp- 
søkte lege da de skadet seg. Kun 53 av de 270 ble diagnostisert med skafoidfraktur akutt, mens 93 frakturer ble oversett av legen. I 60 av disse tilfellene var det tatt røntgenbilder. Kun 30 skafoidfrakturer ble gipsimmobilisert og fikk gjennomført behandlingen etter planen, men sju av disse frakturene var dislokerte og skulle vært operert primært (3). 47 av de 270 pasientene fikk unødvendig gipsbehandling i 2-4 måneder etter at de ble diagnostisert med manifest pseudartrose.

Pseudartrose med inkongruens og feilstilling gir artroseutvikling, som starter radialt og brer seg ulnart og midtkarpalt. Artrose ses hos de fleste pasientene i løpet av 5-10 år (30-32). Ved avansert artrose med betydelige smerter og bevegelsesinnskrenkning har det ingen hensikt å operere pseudartrosen. Avhengig av smerter, artroseutbredelse og funksjonsbehov bør disse pasientene tilbys håndleddsprotese, alternativt delvis/total avstivning av håndleddet (33-35).

Det er konsensus om at skafoidpseudartroser i midtre og distale del uten artroseforandringer bør opereres med avaskulær beintransplantasjon fra crista iliaca eller distale radius, intern fiksasjon med metallpinner eller skruer (fig 5). Det sikreste er å ha gips i 12 uker postoperativt. $85-95 \%$ tilheler, pasientene angir lite smerter og oppnår utmerket håndleddsfunksjon, men ledsagende artrose gir reduksjon $\mathrm{i}$ funksjon $(36-38)$. Lavere tilhelingsfrekvens er beskrevet ved foreldede metoder, der det kun transplanteres bein uten samtidig intern fiksasjon (39). Det er gjennomført to prospektive randomiserte studier av skafoidpseudartroser der stilket vaskularisert radiusbeintransplantat ble sammenliknet med avaskulært cristatransplantat og avaskulært radiustransplantat. Pasientene i den første studien ble gipset i fire uker, og tilhelingsfrekvensen for avaskulært beintransplantat $(73 \%)$ var lavere enn for vaskulært beintransplantat (89\%), men også lavere enn i de fleste retrospektive studiene der pasientene gipses i 8-12 uker. Studien har ikke ført til endring i valg av beintransplantat ved pseudartrosebehandling (40). I den andre studien var tilhelingsfrekvensen lik, og gevinsten av vaskulært beintransplantat var for liten og kunne ikke legitimere den mer omfattende og teknisk krevende prosedyren (41).

Det er uenighet om behandlingen av de mest proksimale skafoidpseudartrosene. Redusert blodsirkulasjon, liten kontaktflate mellom fragmentene, små fragmenter som gir lite tak for fiksasjon, og store krefter som virker over pseudartrosespalten, kan redusere tilhelingen. Standard pseudartroseoperasjon som beskrevet ovenfor benyttes av mange, mens noen foretrekker teknisk kre- vende vaskulære beintransplantat fra distale radius. Resultatene er varierende, og det er ikke holdepunkter for at en metode er bedre enn andre. Uenighet om definisjonen av avaskularitet i skafoid (sklerotisk proksimalt fragment på røntgen, avaskulært fragment sett på MR med kontrast, kirurgens intraoperative vurdering av vaskularitet i fragmentet) gjør det vanskelig å sammenlikne pasientseriene og resultatene $(37,42-44)$. De mest proksimale skafoidpseudartrosene omfatter en svært liten del av pasientene. Det er vår mening at disse bør henvises til håndkirurgiske spesialavdelinger.

\section{Diskusjon}

Utredning og behandling av skafoidfraktur i Norge slik det ble rapportert i 2006 (7) er i tråd med internasjonalt dokumentert god behandling. Raskere rehabilitering og mulighet for tidligere håndleddsaktivitet er gevinsten ved skafoidkirurgi utført i akuttfasen. Dette må veies mot komplikasjonsrisiko. Pasientene i de publiserte studiene er operert av dedikerte håndkirurger med lang erfaring, slik at resultater og komplikasjonsfrekvens må antas å representere det aller beste som kan oppnås.

Den norske tilnærmingen med gipsimmobilisering fra underarm til tommelens interfalangealledd som første valg og tilbud om kirurgi til pasienter som har behov for tidlig mobilisering og som aksepterer den operative komplikasjonsrisikoen, er fornuftig i påvente av at større og bedre studier kan differensiere behandlingen. Ved kirurgi skal frakturen fikseres med skrue (stabil fiksasjon) for å slippe gipsimmobilisering. Skruer kan være vanskelige å plassere korrekt, noe som er kritisk i et område med bruskflater på alle sider. Pasientene bør opereres av kirurger med erfaring i kirurgi på skafoid/ håndrotsknokler. Ellers bør gipsimmobilisering alene være standardbehandling for udislokerte ferske skafoidbrudd uansett hvor de måtte være lokalisert.

Skafoidpseudartroser skilles fra akutte frakturer ved anamnese (tid fra skade) og radiologiske funn (resorpsjon i frakturspalte, sklerotiske frakturender, cyster og økende feilstilling). Disse tilheler ikke med gipsimmobilisering. Det er verdt å granske røntgenbilder og sykehistorie for å skille ut eldre skader. Langtidsresultatene etter vellykket pseudartrosekirurgi er gode ved tidlig diagnostikk og normale leddflater. Det kliniske resultatet forverres ved reoperasjoner og sekundære artroseforandringer $(38,42)$. Om den sekundære artrosen er tilstrekkelig smertefull og omfatter radioskafoidleddfasetten eller større deler av leddet, kan pasienten tilbys delvis avstiving av håndleddet (firebeinsartrodese), håndleddsprotese eller total avstivning.
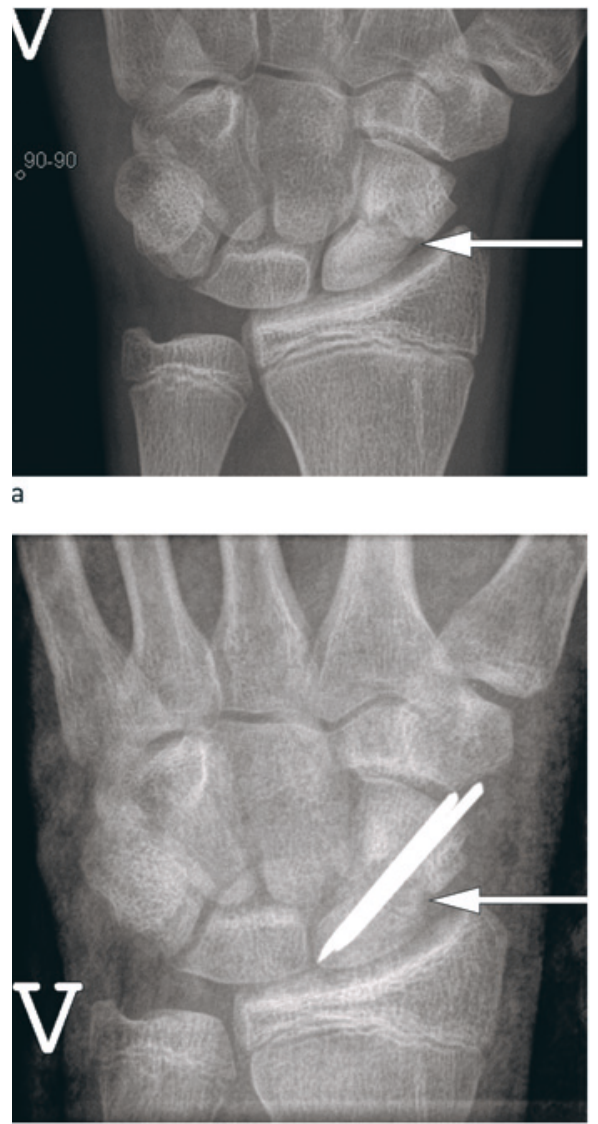

b

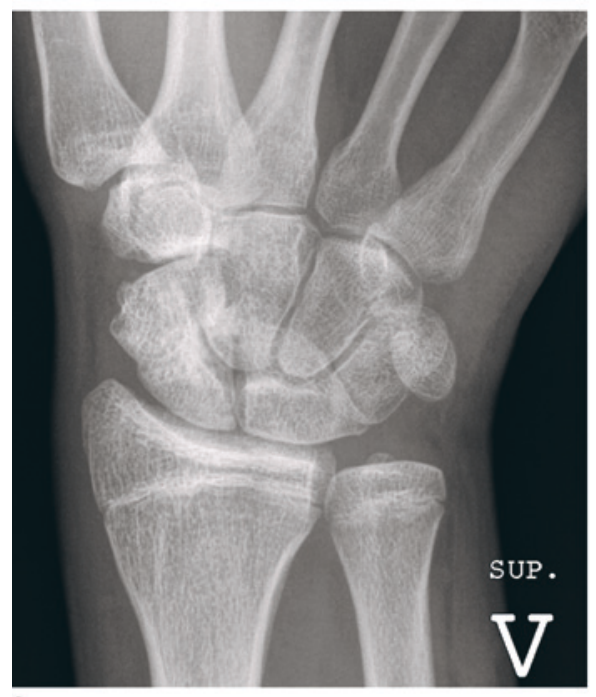

Figur 5 Behandling av skafoidpseudartrose. a) 18 måneder gammel skafoid pseudartrose (hvit pil) hos ung mann, b) Operert med beintransplantasjon fra crista og 1,6 mm glatte metallpinner. Postoperativt bilde med gips, pil på beingraft, c) Avsluttende kontroll etter 14 måneder. Normal håndleddsfunk sjon, ingen sekundær håndleddsartrose, beingraft inkorperert i skafoid 


\section{Ole Reigstad (f. 1969)}

er ph.d., spesialist i ortopedisk kirurgi og overlege med norsk diplom i håndkirurgi.

Forfatter har fylt ut ICMJE-skjemaet og oppgir ingen interessekonflikter.

\section{Rasmus Thorkildsen (f. 1970)}

er spesialist i ortopedisk kirurgi og overlege med norsk diplom i håndkirurgi.

Forfatter har fylt ut ICMJE-skjemaet og oppgir ingen interessekonflikter.

\section{Christian Grimsgaard (f. 1969)}

er spesialist i ortopedisk kirurgi og overlege med norsk diplom i håndkirurgi.

Forfatter har fylt ut ICMJE-skjemaet og oppgir ingen interessekonflikter.

\section{Knut Melhuus (f. 1955)}

er lege og seksjonsleder.

Forfatter har fylt ut ICMJE-skjemaet og oppgir ingen interessekonflikter.

\section{Magne Røkkum (f. 1953)}

er dr.med., spesialist i ortopedisk kirurgi og overlege med norsk diplom i håndkirurgi. Forfatter har fylt ut ICMJE-skjemaet og oppgir ingen interessekonflikter.

\section{Litteratur}

1. Gelberman RH, Menon J. The vascularity of the scaphoid bone. J Hand Surg Am 1980; 5: 508-13.

2. Oehmke MJ, Podranski T, Klaus R et al. The blood supply of the scaphoid bone. J Hand Surg Eur Vol 2009; 34: $351-7$

3. Reigstad O, Grimsgaard C. Thorkildsen R et al. Scaphoid non-unions, where do they come from? The epidemiology and initial presentation of 270 scaphoid non-unions. Hand Surg 2012; 17: $331-5$

4. Glad TH, Melhuus K, Svenningsen S. Bruk av MR ved skafoidfraktur. Tidsskr Nor Legeforen 2010; 130: $825-8$

5. Hove LM. Epidemiology of scaphoid fractures in Bergen, Norway. Scand J Plast Reconstr Surg Hand Surg 1999; 33: 423-6.

6. Larsen CF. Brøndum V. Skov O. Epidemiology of scaphoid fractures in Odense, Denmark. Acta Orthop Scand 1992; 63: 216-8.

7. Thorkildsen R, Reigstad O, Grimsgaard C. Behandling av skafoidfraktur og pseudartrose i Norge 2006 . Oslo: Norsk kirurgisk høstmøte, 2006.

8. Parvizi J, Wayman J, Kelly P et al. Combining the clinical signs improves diagnosis of scaphoid fractures. A prospective study with follow-up. J Hand Surg [Br] 1998; 23: 324-7.

9. Bergh TH, Lindau T, Soldal LA et al. Clinical scaphoid score (CSS) to identify scaphoid fracture with MRI in patients with normal $x$-ray after a wrist trauma. Emerg Med J 2014; 31: 659-64.
10. Memarsadeghi M, Breitenseher MJ, SchaeferProkop C et al. Occult scaphoid fractures: comparison of multidetector $\mathrm{CT}$ and MR imaging - initial experience. Radiology 2006; 240: 169-76.

11. Rhemrev SJ, van Leerdam RH, Ootes D et al. Nonoperative treatment of non-displaced scaphoid fractures may be preferred. Injury 2009; 40: $638-41$

12. Patillo DP, Khazzam M, Robertson MW et al. Outcome of percutaneous screw fixation of scaphoid fractures. J Surg Orthop Adv 2010; 19: 114-20.

13. Langhoff $O$, Andersen JL. Consequences of late immobilization of scaphoid fractures. J Hand Surg [Br] 1988; 13: 77-9

14. Hambidge JE, Desai VV, Schranz PJ et al. Acute fractures of the scaphoid. Treatment by cast immobilisation with the wrist in flexion or extension? J Bone Joint Surg Br 1999; 81: 91-2.

15. Gellman H, Caputo RJ, Carter V et al. Comparison of short and long thumb-spica casts for non-displaced fractures of the carpal scaphoid. J Bone Joint Surg Am 1989; 71: $354-7$

16. Clay NR, Dias JJ, Costigan PS et al. Need the thumb be immobilised in scaphoid fractures? A randomised prospective trial. J Bone Joint Surg $\mathrm{Br}$ 1991: 73: 828-32.

17. Adolfsson L, Lindau T, Arner M. Acutrak screw fixation versus cast immobilisation for undisplaced scaphoid waist fractures. J Hand Surg [Br] 2001 26: $192-5$.

18. Vinnars B. Pietreanu M, Bodestedt A et al. Nonoperative compared with operative treatment of acute scaphoid fractures. A randomized clinical trial. J Bone Joint Surg Am 2008; 90: 1176-85.

19. Bond CD, Shin AY, McBride MT et al. Percutaneous screw fixation or cast immobilization for nondisplaced scaphoid fractures. J Bone Joint Surg Am 2001; 83-A: 483-8.

20. Dias JJ, Dhukaram V, Abhinav A et al. Clinica and radiological outcome of cast immobilisation versus surgical treatment of acute scaphoid fractures at a mean follow-up of 93 months. J Bone Joint Surg Br 2008; 90: 899-905

21. McQueen MM, Gelbke MK, Wakefield A et al. Percutaneous screw fixation versus conservative treatment for fractures of the waist of the scaphoid: a prospective randomised study. J Bone Joint Surg Br 2008: 90: 66-71.

22. Saedén B, Törnkvist $H$, Ponzer $S$ et al. Fracture of the carpal scaphoid. A prospective, randomised 12-year follow-up comparing operative and conservative treatment. J Bone Joint Surg Br 2001 83: $230-4$.

23. Dias JJ, Wildin CJ, Bhowal B et al. Should acute scaphoid fractures be fixed? A randomized controlled trial. J Bone Joint Surg Am 2005; 87 2160-8.

24. Ram AN, Chung KC. Evidence-based management of acute nondisplaced scaphoid waist fractures. J Hand Surg Am 2009; 34: 735-8.

25. Modi CS, Nancoo T, Powers D et al. Operative versus nonoperative treatment of acute undis placed and minimally displaced scaphoid waist fractures - a systematic review. Injury 2009; 40 $268-73$

26. Yin ZG, Zhang JB, Kan SL et al. Treatment of acute scaphoid fractures: systematic review and metaanalysis. Clin Orthop Relat Res 2007; 460: 142-51.

27. Grewal R, King GJ. An evidence-based approach to the management of acute scaphoid fractures. J Hand Surg Am 2009; 34: 732-4.
28. Herzberg G, Comtet JJ, Linscheid RL et al. Perilunate dislocations and fracture-dislocations: a multicenter study. J Hand Surg Am 1993: 18: 768-79.

29. Wolfe SW. Green's operative hand surgery. 6. utg Philadelphia, PA: Elsevier, 2011

30. Düppe H, Johnell O, Lundborg $G$ et al. Long-term results of fracture of the scaphoid. A follow-up study of more than thirty years. J Bone Joint Surg Am 1994; 76: 249-52

31. Inoue G, Sakuma M. The natural history of scaphoid non-union. Radiographical and clinical analysis in 102 cases. Arch Orthop Trauma Surg 1996; 115: $1-4$

32. Vender MI, Watson HK, Wiener BD et al. Degenerative change in symptomatic scaphoid nonunion. J Hand Surg Am 1987; 12: 514-9.

33. Reigstad O, Lütken T, Grimsgaard $C$ et al. Promising one- to six-year results with the Motec wrist arthroplasty in patients with post-traumatic osteoarthritis. J Bone Joint Surg Br 2012; 94: 1540-5

34. Adey L, Ring D, Jupiter JB. Health status after total wrist arthrodesis for posttraumatic arthritis. J Hand Surg Am 2005; 30: 932-6.

35. Dacho A, Grundel J, Holle G et al. Long-term results of midcarpal arthrodesis in the treatment of scaphoid nonunion advanced collapse (SNACWristl and scapholunate advanced collapse (SLAC-Wrist). Ann Plast Surg 2006; 56: 139-44.

36. Huang YC, Liu Y, Chen TH. Long-term results of scaphoid nonunion treated by intercalated bone grafting and Herbert's screw fixation - a study of 49 patients for at least five years. Int Orthop 2009; 33: $1295-300$

37. Finsen V, Hofstad M, Haugan H. Most scaphoid nonunions heal with bone chip grafting and Kirschnerwire fixation. Thirty-nine patients reviewed 10 years after operation. Injury 2006; 37: 854-9

38. Reigstad O, Grimsgaard C, Thorkildsen R et al. Long-term results of scaphoid nonunion surgery: 50 patients reviewed after 8 to 18 years. J Orthop Trauma 2012; 26: 241-5

39. Kołodziej RK, Blacha J, Bogacz A et al. Long-term outcome of scaphoid nonunion treated by the Matti-Russe operation. Ortop Traumatol Rehabil 2006: 8: 507-12

40. Ribak S, Medina CE, Mattar R Jr et al. Treatment of scaphoid nonunion with vascularised and nonvascularised dorsal bone grafting from the distal radius. Int Orthop 2010: 34: 683-8.

41. Caporrino FA, Dos Santos JB, Penteado FT et al. Dorsal vascularized grafting for scaphoid nonunion: a comparison of two surgical techniques. J Orthop Trauma 2014: 28: e44-8.

42. Reigstad O, Thorkildsen R, Grimsgaard C et al. Is revision bone grafting worthwhile after failed surgery for scaphoid nonunion? Minimum 8 year follow-up of 18 patients. J Hand Surg Eur Vol 2009 34: $772-7$

43. Malizos KN, Dailiana ZH, Kirou M et al. Longstanding nonunions of scaphoid fractures with bone loss: successful reconstruction with vascularized bone grafts. J Hand Surg [Br] 2001; 26: 330-4.

44. Kapoor AK, Thompson NW Rafiq I et al Vascularised bone grafting in the management of scaphoid non-union - a review of 34 cases. J Hand Surg Eur Vol 2008; 33: 628-31.

Mottatt 10.10. 2014, første revisjon innsendt 9.2 2015, godkjent 28.4. 2015. Redaktør: Sigurd Høye. 